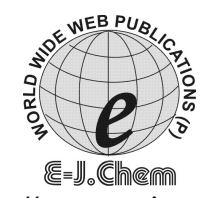

http://www.e-journals.net

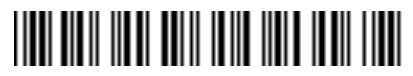

ISSN: 0973-4945; CODEN ECJHAO

E-Journal of Chemistry

Vol. 4, No. 4, pp. 587-605, October 2007

\title{
Sorption Behavior of Cu(II) From Acidic Solution Using Weathered Basalt Andesite Products
}

\author{
RAJESH SINGH, AJAY V. SHAH ${ }^{\#}$, and BHAVNA A. SHAH* \\ Department of Chemistry, \\ Veer Narmad South Gujarat University, Surat - 395007, India \\ "Polytechnic Vidhyabharti Trust, Umrkh, Bardoli - 394601, INDIA \\ rs.chemistry@gmail.com
}

Received 22 April 2007; Accepted 15 June 2007

\begin{abstract}
Wastewater discharged from electroplating industry pose a serious hazard due to their heavy metal load. The objective of this work is to evaluate the removal of $\mathrm{Cu}(\mathrm{II})$ from acidic solution by sorption onto Weathered Basalt Andesite Products (WBAP). WBAP has been characterized and utilized for removal of copper from aqueous solution over wide range of initial metal ion concentration $(25 \mathrm{mg} / \mathrm{L}$ to $500 \mathrm{mg} / \mathrm{L})$, contact duration $(0-8 \mathrm{~h})$, sorbent dose (5-35 g/L), $\mathrm{pH}(1.0$ to 6.0$)$, and temperature (276 K to $333 \mathrm{~K})$. The sorption pattern of $\mathrm{Cu}$ ions onto WBAP followed Langmuir, Freundlich, and DubininKaganer-Radushkevich isotherms. The thermodynamic parameters $\left(\Delta H^{0}, \Delta S^{0}\right.$, and $\Delta \mathrm{G}^{0}$ ) for $\mathrm{Cu}$ sorption onto WBAP were also determined.
\end{abstract}

Keywords: Sorption, Isotherms, Lagergren's equation, Kinetics

\section{Introduction}

Industrialization and urbanization have led to an increase in ecological problems. Water is particularly vulnerable to contamination from discharge of wastewater by various industries $^{1,2}$. The presence of heavy metals in the environment can be detrimental to a variety of living species. Metals can be distinguished from other toxic pollutants, because these are non biodegradable, may undergo transformation, and can have a large environmental, public health, and economic impact, ${ }^{3,4}$. This has led to more stringent legislation and has prompted industries to seek more effective methods of pollution control, as the maximum permissible limits are reduced ${ }^{5}$.

Copper is a toxic element that can be rarely found in the upstream of rivers, but make its own way through industrial discharge streams, such as battery \& power storage, coatings, 
and electroplating industries. The human body requires $\mathrm{Cu}$ in small quantities, but when this concentration exposure reaches $1.3 \mathrm{mg} / \mathrm{dm}^{3}$ for short duration, stomach and intestinal problems occurs. Long term exposure leads to liver and kidney damage, as well as accumulation in the brain. Excess dose also leads to severe mucosal irritation and corrosion, widespread capillary damage, hepatic and renal damage, and central nervous system irritation followed by depression. It is also toxic to fish life, when its content is small enough in water ${ }^{6}$. Although the maximum permissible concentration by WHO and USPHS is 1.5 and $1.0 \mathrm{mg} / \mathrm{dm}^{3}$, respectively, the maximum recommended concentration of $\mathrm{Cu}^{2+}$ for drinking water by these agencies is $1.0 \mathrm{mg} / \mathrm{dm}^{3}$.

The $\mathrm{Cu}$ level in wastewater, drinking water, and water used for agriculture need must be reduced to the maximum permissible concentration. Precipitation, ion-exchange, solvent extraction, reverse osmosis, electro dialysis, and adsorption onto activated carbon are the conventional methods for the removal of heavy metal ions from aqueous solution ${ }^{7-9}$.

Traditional treatments are often of limited effectiveness and may be incapable of meeting the decreasing allowable levels specified by regulatory agencies. The limitation and cost of treatment methods has led researchers to search for alternatives ${ }^{10}$. Activated carbons are the most common and promising adsorbent, but the use of activated carbon is limited especially in developing countries, because of its high cost and difficulties in the regeneration ${ }^{11,12}$. Evaluation of biosorbents for metal ions has been well studied ${ }^{13-15}$. Studies have been conducted to evaluate the potential of clay minerals like montmorillonite, kaolinite, illite, bentonite, and sepiolite ${ }^{16-19}$.

However, after the vast literature survey, it was found that very little work has been done on andesite ${ }^{20,21}$, rich in silica, aluminum, and iron. The abundance of WBAP and its low cost are likely to make it a strong candidate as a sorbent for the removal of heavy metal ions from wastewater. The study was therefore undertaken to understand the mechanism involved in the affinity, selectivity \& capacity of WBAP towards metal ion, for the removal of $\mathrm{Cu}$ ion from very acidic condition, as the $\mathrm{pH}$ of electroplating wastewater is highly acidic.

\section{Experimental}

\section{Source and Conditioning}

WBAP, gray in color, was obtained from weathered Basalt deposit in Kutch region of Gujarat (India). This material was first treated with $\mathrm{H}_{2} \mathrm{O}_{2}$ at room temperature for 24 hour to oxidize the adhering organic matter and washed with demineralized water. Preliminary sorption studies revealed that heating the sorbent at $100{ }^{0} \mathrm{C}$ retards the sorption characteristics; therefore WBAP was dried in open atmosphere and then stored in a polypropylene container in a desiccator. No other physical or chemical treatments used prior to sorption experiment. Chemical composition of WBAP sample was determined by the usual analytical methods for silicate materials ${ }^{22,23} \cdot \mathrm{Al}_{2} \mathrm{O}_{3}, \mathrm{Fe}_{2} \mathrm{O}_{3}$, and $\mathrm{P}_{2} \mathrm{O}_{5}$ were analyzed by Hach $\mathrm{DR} / 2500$ spectrophotometer. $\mathrm{CaO}$ and $\mathrm{MgO}$ were analyzed with titrimetry and $\mathrm{SiO}_{2}$ was analyzed with gravimetry. $\mathrm{Na}_{2} \mathrm{O}$ and $\mathrm{K}_{2} \mathrm{O}$ were found by Systronics flame photometer 128 .

\section{Reagents}

Demineralized water with conductivity $1.0 \mu \mathrm{S} / \mathrm{cm}$ was used after distillation. The chemicals used in the investigation were supplied by Rankem as analytical grade reagents. We prepared synthetic stock solution of $\mathrm{Cu}$ using its nitrate salt in demineralized water. Nitrate salts were preferred to facilitate the solubilization and to eliminate metal precipitation. 


\section{Analytical}

The $\mathrm{pH}$ of all solutions was measured on Systronics (instrument model 361) pH meter. The concentration of metal ion was analyzed using Hach DR/2500 spectrophotometer after 1:10 dilution $^{24}$. The IR spectra of the samples were recorded on Thermo-Nicolet Nexus FT-IR spectrometer. SEM images were acquired by using a LEO 435 VP scanning electron microscope (LEO Electron Microscopy Ltd., Cambridge, England) operating at $15 \mathrm{kV}$. Philips EM-400 transmission electron microscope (Einhoven, The Netherlands) with a maximum accelerating voltage of $120 \mathrm{kV}$ was employed to obtain the high resolution images and SAED patterns. X-ray diffraction patterns of the sample were recorded on a Bruker AXS D8 Advance diffractometer employing $\mathrm{Cu}-\mathrm{K}_{\alpha}(\lambda=1.54060 \AA)$ radiations and $\mathrm{Ni}$ filter at $40 \mathrm{kV}$ to record a pattern in the $2 \theta$ range of $5-120^{\circ}$. The thermal analysis of the samples were performed using a Perkin Elmer Pyris Diamond TG/TGA instrument at a fixed heating rate of $10{ }^{\circ} \mathrm{C} / \mathrm{min}$ over a temperature range of $26-1000{ }^{\circ} \mathrm{C}$ using alumina powder $(10$ $\mathrm{mg}$ ) as reference. The degradation runs were taken under oxidizing atmosphere (flowing dry air) at a flow rate of $200 \mathrm{~mL} /$ minute. The density of the sorbent was determined by specific gravity bottles. The sorption experiment were studied by batch technique using laboratory scale stirred tank reactors (STR), equipped with six glass vessel of 1 liter and twin blade impeller driven by a variable speed motor. The impeller speed was set at $100 \mathrm{rpm}$. At increasing time intervals aliquots of sample were withdrawn by plastic syringe.

\section{Calculations}

The metal concentration in the liquid phase was determined at the beginning $\left(\mathrm{C}_{\mathrm{i}}\right)$ and after equilibration time $\left(\mathrm{C}_{\mathrm{f}}\right)$. The following equations were used to compute the percent metal uptake by sorbent-

$$
\begin{aligned}
& \text { \% sorption }=\left\{\left(\mathrm{C}_{\mathrm{i}}-\mathrm{C}_{\mathrm{f}}\right) / \mathrm{C}_{\mathrm{i}}\right\} \times 100 \\
& \text { Distribution Coefficient, } \mathrm{K}_{\mathrm{d}}=\left\{\left(\mathrm{C}_{\mathrm{i}}-\mathrm{C}_{\mathrm{f}}\right) / \mathrm{C}_{\mathrm{f}}\right\} \times(\mathrm{V} / \mathrm{m}) \\
& \text { Where } \mathrm{V} \text { is volume of solution }(\mathrm{mL}) \text { and } \mathrm{m} \text { is the mass of sorbent }(\mathrm{g}) \text {. }
\end{aligned}
$$

\section{Sorption procedure}

Pre weighed sample of the sorbent and a measured volume of $\mathrm{Cu}(\mathrm{II})$ solution were taken in $1 \mathrm{~L}$ glass vessel of STR and the mixture was agitated for a constant time. The impeller speed was set at 100rpm. At increasing time intervals aliquots of sample were withdrawn by plastic syringe, filtered, and after dilution of 1:10, analyzed with spectrophotometer. The experiments were carried out by varying amount of sorbent $(5-35 \mathrm{~g} / \mathrm{L})$, contact time $(0-8$ hours), $\mathrm{pH}$ (1.0 to 6.0), initial metal ion concentration (25 ppm to $500 \mathrm{ppm}$ ), and temperature $(276 \mathrm{~K}$ to $333 \mathrm{~K})$. Each experiment was carried out in triplicate and the average results are presented.

\section{Result and Discussion}

Chemical constituents of the WBAP as determined by using standard methods of chemical analysis are $\mathrm{SiO}_{2}, 55.09 \% ; \mathrm{Al}_{2} \mathrm{O}_{3}, 10.48 \% ; \mathrm{Fe}_{2} \mathrm{O}_{3}, 13.32 \% ; \mathrm{CaO}, 4.80 \% ; \mathrm{Na}_{2} \mathrm{O}, 2.46 \% ; \mathrm{K}_{2} \mathrm{O}$, $0.19 \%$; Loss on ignition, $16.88 \%$ by weight. Two gram sample of WBAP was stirred with demineralized water $(100 \mathrm{~mL}, \mathrm{pH} 6.59)$ for $24 \mathrm{~h}$ in an air tight stoppered conical flask. An enhancement in $\mathrm{pH} 9.66$ was noticed. It is quite stable in water, salt solution, acids and bases.

The X-ray diffraction pattern (Figure. 1) of the sorbent provided d spacing values which reflect the presence of Illite $(4.447,3.3466,2.5704,9.698,2.455,1.4928 \AA$ ), Montmorillonite (14.859, 4.447, 3.06, $1.4928 \AA)$, Paragonite / Mica (2.515, 3.1915, 9.6985 $\AA)$, Tetrakalsilite $(3.0697,2.8969,4.447 \AA)$, Faujasite $(14.859,3.1915,2.51 \AA)$, Kaolinite 
(7.23302, $3.52494 \AA)$, and Geothite (2.4555 $)$ ) indicating a high chemical stability. After sorption, the change in diffraction pattern is clearly noticeable and diffraction pattern for copper silicate $(1.49$ and $2.96 \AA$ ) was observed. The original WBAP has a $d$-spacing of $14.859 \AA$ which increased to 15.112 because of expansion in the interlayer spacing.

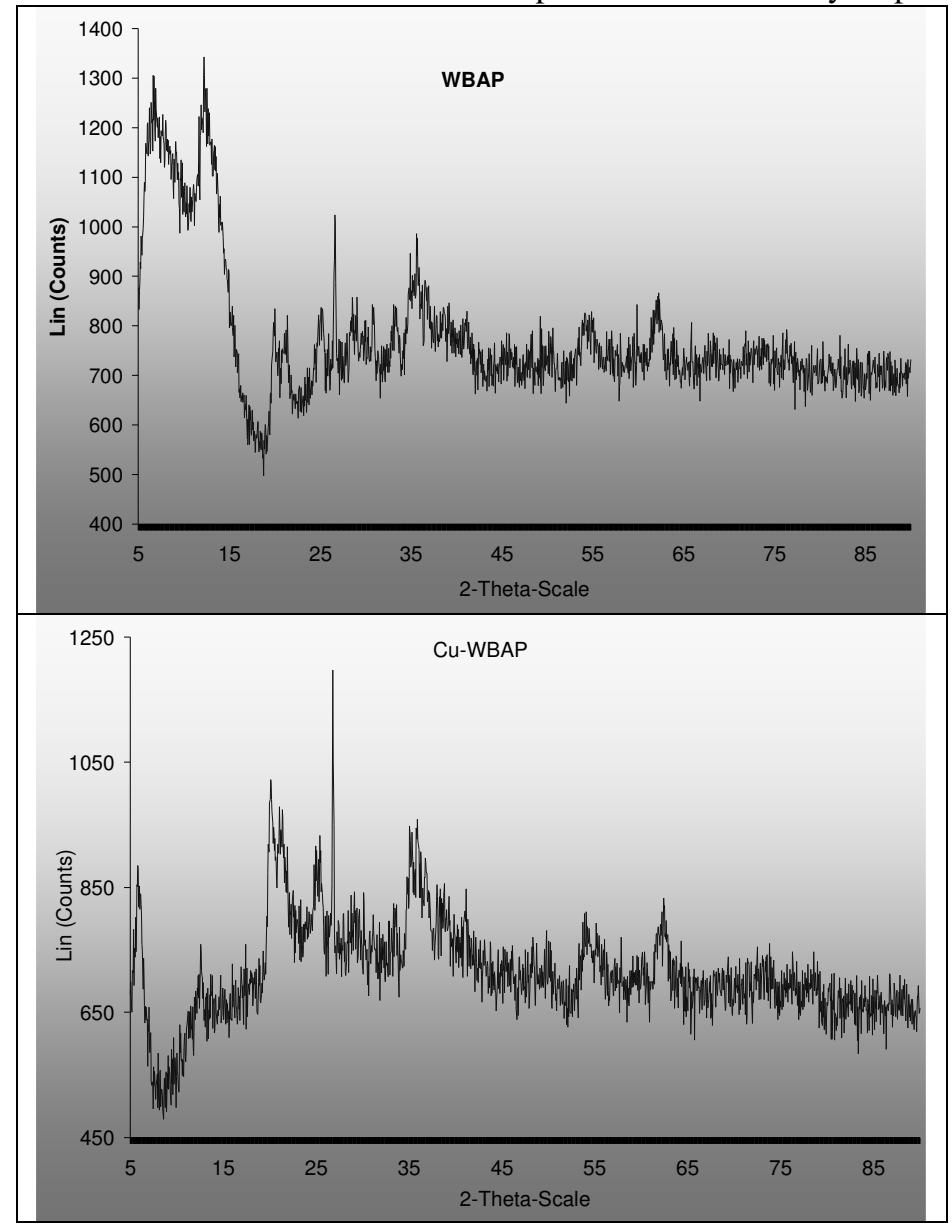

Figure 1. PXRD pattern of WBAP and Cu sorbed WBAP.

Infra red spectra (Figure not shown) of WBAP indicated weak and broad peaks in the region of $4000-300 \mathrm{~cm}^{-1}$. The absorbance bands in the region $3700-3420 \mathrm{~cm}^{-1}$ is assigned to free $-\mathrm{OH}$ group and represents the fundamental stretching vibrations of different $-\mathrm{OH}$ groups present in $\mathrm{Al}-\mathrm{OH}-\mathrm{Al}$ and $\mathrm{Fe}-\mathrm{OH}-\mathrm{Al}$ units in the octahedral layer. The absorption peak at $3620 \mathrm{~cm}^{-1}$ indicates the presence of interlayer hydrogen bonding. The bending mode of $\mathrm{Al}-\mathrm{OH}-\mathrm{Al}$ appeared in the region of $914 \mathrm{~cm}^{-1}$. Bands observed at $980-1100,800$, and $695 \mathrm{~cm}^{-1}$ were attributed to $\mathrm{Si}-\mathrm{O}$ stretching vibrations. The absorption band at 1637 is due to reversibly adsorbed carbonate on oxide surface. The asymmetric bending mode of Si-O appeared in the region $456 \mathrm{~cm}^{-1}$. The peak at $530 \mathrm{~cm}^{-1}$ is due to Si-O-Al (octahedral). The absorption band at $3696 \mathrm{~cm}^{-1}$ indicated the presence of kaolinite. A very weak band at 360 $\mathrm{cm}^{-1}$ was due to presence of hematite. A strong band at $467 \mathrm{~cm}^{-1}$ suggests the presence of 
calcium silicate. The peak at $576 \mathrm{~cm}^{-1}$ may be due to the presence of $\mathrm{Al}_{2} \mathrm{O}_{3}$. The peak at 360 and $467 \mathrm{~cm}^{-1}$ may be due to the presence of hematite and calcium silicate respectively.

SEM photographs of WBAP at 2 different magnifications i.e. 1 × 700, and 1 × 2000, (Figure 2) helped in recognizing the texture of aluminum silicates distributed with constituents like $\mathrm{Fe}, \mathrm{Ca}$ etc. The SEM photograph indicates WBAP to be highly porous, which is in agreement with the porosity value. It shows that WBAP composed of smooth as well as rough surfaces. The smooth areas are characterized by a ditch like structure resembling series of lines with few macropores. The rough surface micrograph shows ridge like structure within which the presence of the macropores is clearly noticeable. These rough surfaces and the macropores were responsible for the high surface area, making WBAP a good sorbent. Based on the analysis of images, taken by SEM before and after the sorption process, two types of sorption are observed. A horizontal layer type of sorption is observed on the smooth surface, whereas accumulation of contaminants on the edges of the rough surfaces as well as in the macropores is observed. The images also indicate towards the possibility of multilayer sorption. After sorption, the WBAP particles seem to be more fluffy and porous. This may be due to the change in surface charge of the particle as a result of introduction of contaminants.
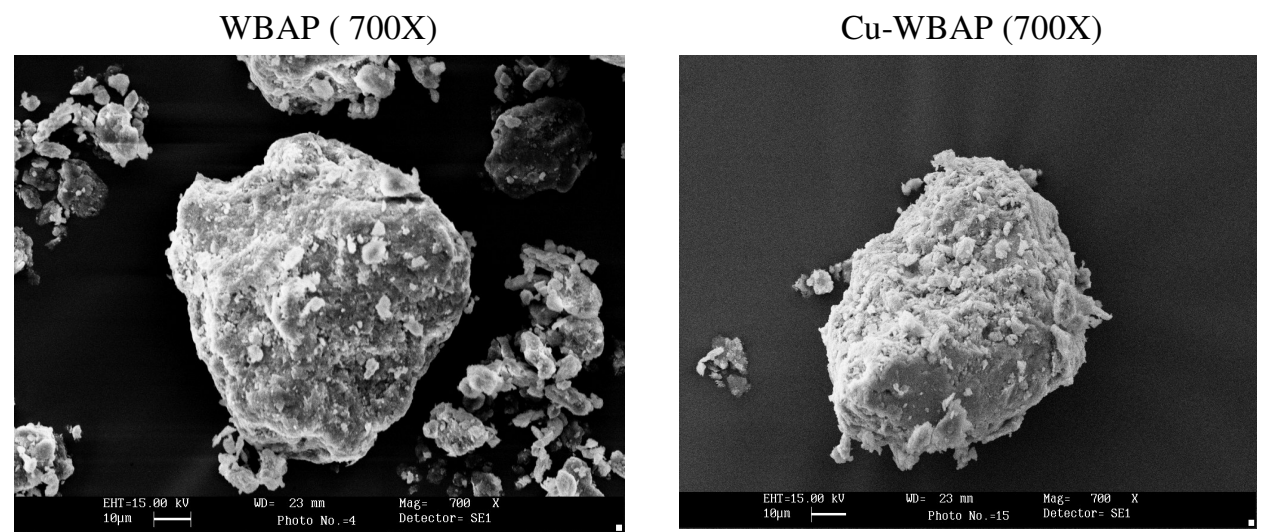

WBAP (2000X)
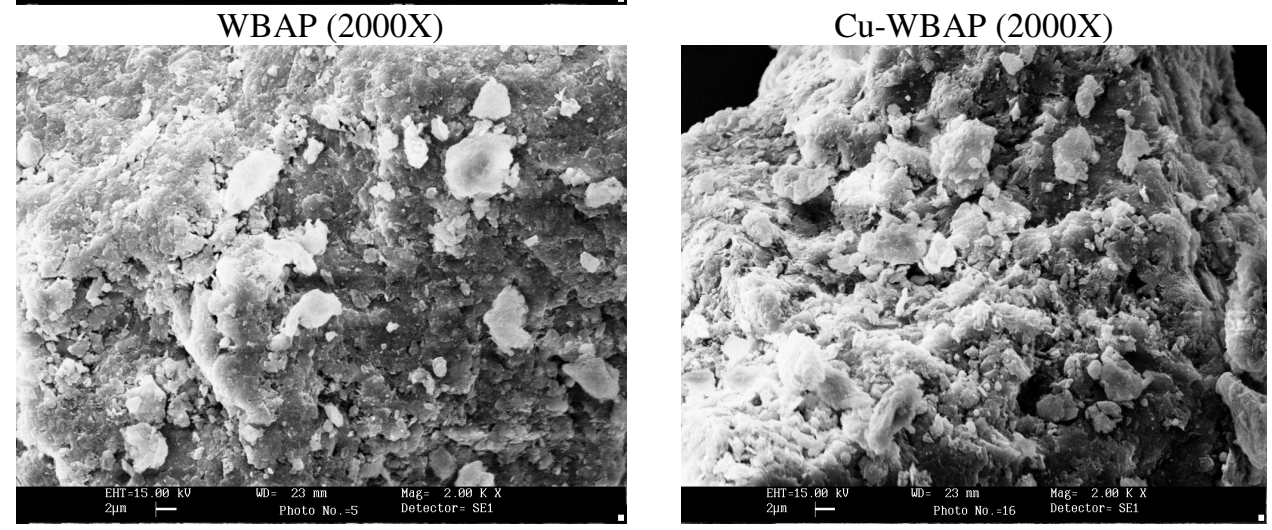

Figure 2. SEM photographs of WBAP and Cu sorbed WBAP.

TEM image of WBAP before and after sorption at 2700 magnification (Figure 3) clearly indicates the increase in electron density. Diffraction spots in the SAED images for 
sorbent may be due to the presence of heavy metals like iron, but the prominent rings indicate the polycrystalline nature of WBAP. Comparing the diffraction spots observed in the SAED pattern obtained for the virgin and sorbed WBAP, increase in diffraction spots is also observed. The number of diffraction spots obtained for the rough surface is much more than that for smooth surfaces (image not given).
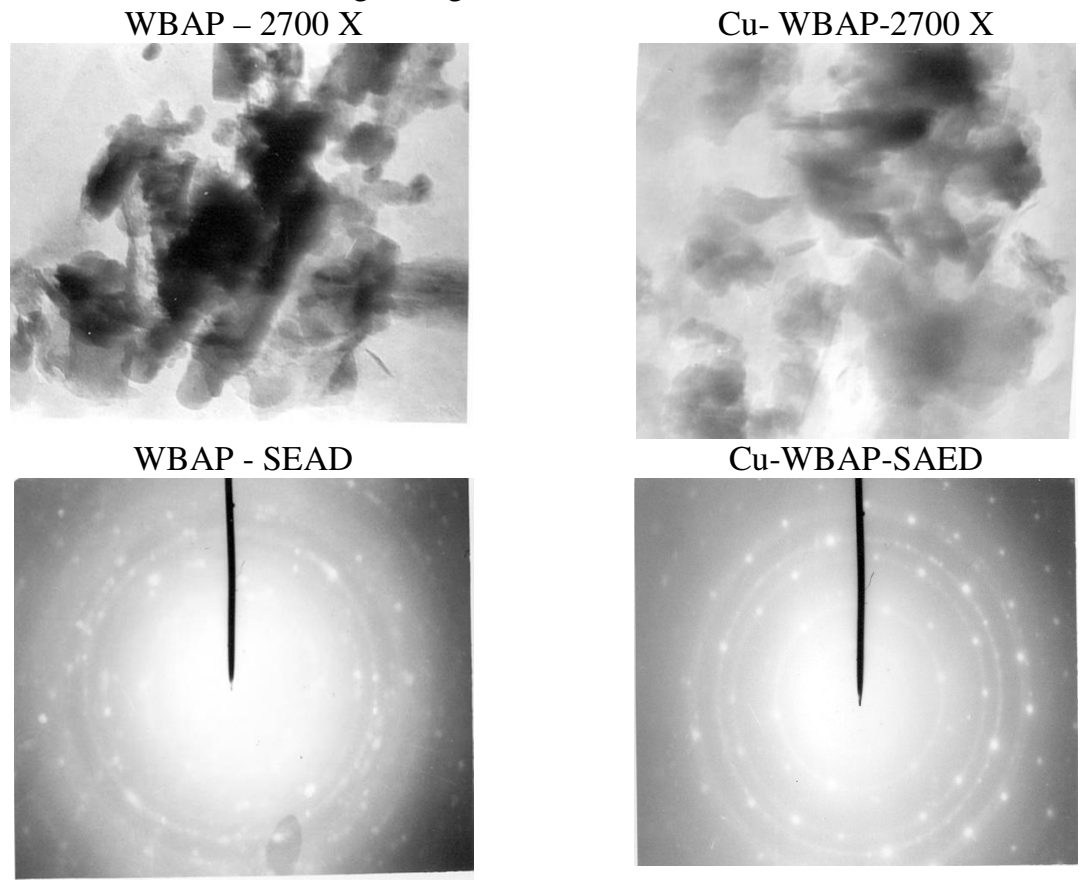

Figure 3. TEM photographs and SAED pattern of WBAP and $\mathrm{Cu}$ sorbed WBAP.

The DTA-TGA curves not shown here indicate first loss of weight $(6.7 \%)$ between 25 and $125^{\circ} \mathrm{C}$. These transformations are due to the removal of adsorbed water from between the silicate sheets. The DTA curve shows the process to be endothermic. A small endothermic peak between $225-290{ }^{\circ} \mathrm{C}$ is observed, which corresponds to loss of interlayer water molecules $(1.04 \%)$. The third loss of weight $(7 \%)$ takes place between $370-500{ }^{\circ} \mathrm{C}$, and is completed at $750{ }^{\circ} \mathrm{C}$ due to loss of structural water i.e. the hydroxyl groups from the WBAP. This step is also endothermic in nature. Further heating, does not show any change. The kinetic parameters for these decomposition steps were evaluated by Coats and Redfern method ${ }^{25}$. The value of energy of activation (E) and preexponential factor (A) was calculated from the slope and intercept of the best fit curve (Figure 4). Following equations were employed to calculate the entropy of activation (Eq. 3), the enthalpy of activation (Eq. 4), and free energy of activation (Eq. 5):

$$
\begin{aligned}
& \mathrm{S}^{*}=2.303[\log (\mathrm{Ah} / \mathrm{KT})] \mathrm{R} \\
& \mathrm{H}^{*}=\mathrm{E}^{*}-\mathrm{RT} \\
& \mathrm{G}^{*}=\mathrm{H}-\mathrm{TS}
\end{aligned}
$$

where $\mathrm{h}$ and $\mathrm{K}$ are Planck's and Boltzmann constants, respectively. The data are given in Table 1 . The negative value of $\mathrm{S}^{*}$ and positive value of $\mathrm{G}^{*}$ indicates that the decomposition reaction is slow. The surface area was found to be $618.25 \mathrm{~m}^{2} / \mathrm{g}$. The point of zero charge was determined by potentiometric titration method ${ }^{25}$. The characteristics of the sorbent are pHzpc 2.4 , density $1.16 \mathrm{~g} / \mathrm{cm}^{3}$, porosity 0.4378 fraction, and void ratio 0.779 . 


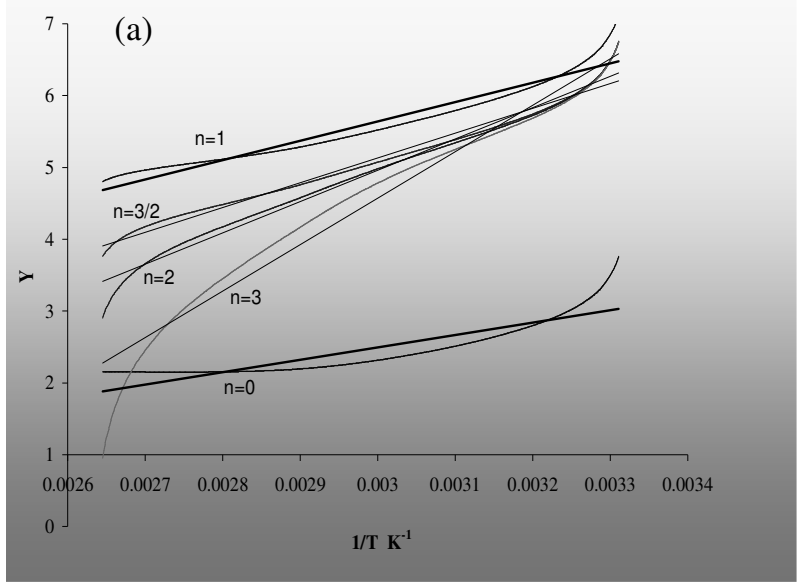

(b)
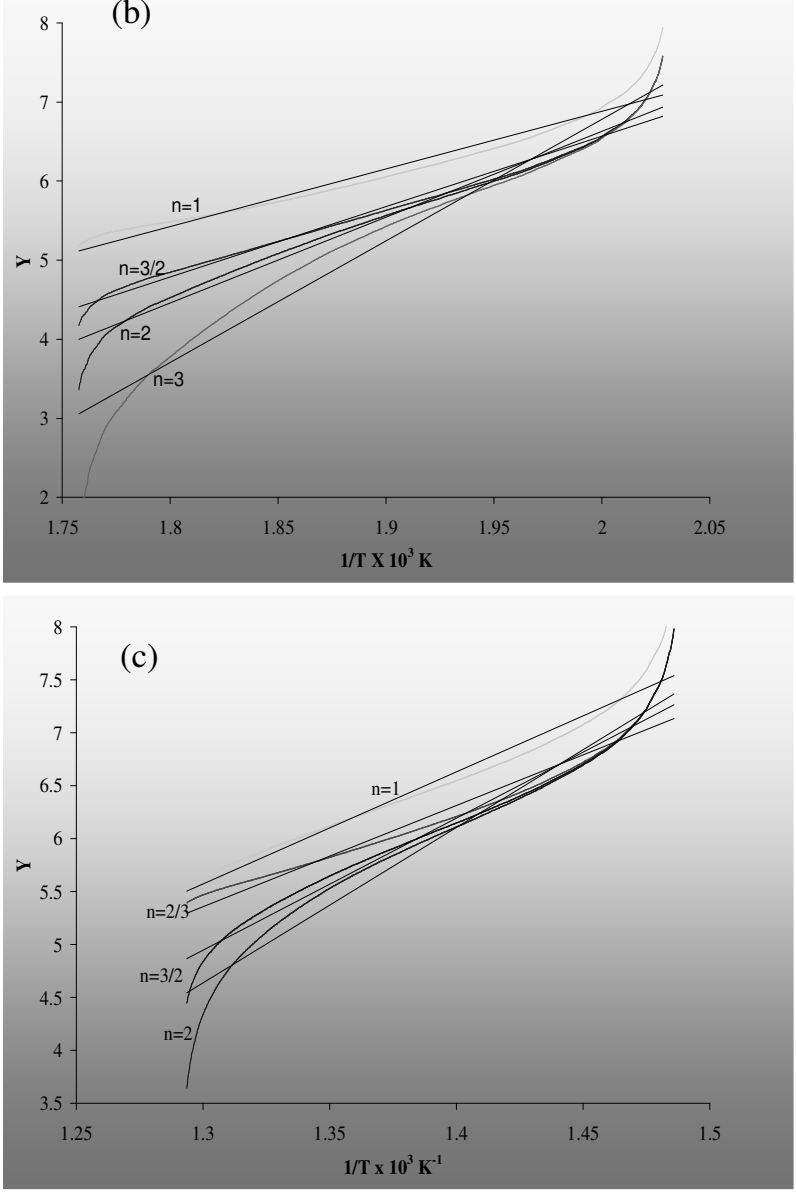

Figure 4. Plots of Coats and Redfern Method (a) Step I, (b) Step II, (c) Step III. 
Table 1. Kinetic data of the thermal decomposition of the sorbent

\begin{tabular}{lll}
\hline Step of degradation & Parameters & Result \\
\hline Step 1 (30-110 $\left.{ }^{\circ} \mathrm{C}\right)$ & Order of decomposition & 2 \\
& $\mathrm{E}^{*}, \mathrm{~kJ} / \mathrm{mol}$ & 64.2636 \\
& $\mathrm{~A}, \mathrm{~S}^{-1}$ & $7.0736 \times 10^{8}$ \\
& $\mathrm{~S}^{*}, \mathrm{~J} / \mathrm{K} / \mathrm{mol}$ & -76.5068 \\
& $\mathrm{H}^{*}, \mathrm{~kJ} / \mathrm{mol}$ & 61.469 \\
& $\mathrm{G}^{*}, \mathrm{~kJ} / \mathrm{mol}$ & 87.1818 \\
Step 2 (210-290 $\left.{ }^{\circ} \mathrm{C}\right)$ & $\mathrm{Order}^{*}$ of decomposition & $3 / 2$ \\
& $\mathrm{E}^{*}, \mathrm{~kJ} / \mathrm{mol}$ & 121.145 \\
& $\mathrm{~A}, \mathrm{~S}^{-1}$ & $3.2122 \mathrm{X} 10^{10}$ \\
& $\mathrm{~S}^{*}, \mathrm{~J} / \mathrm{K} / \mathrm{mol}$ & -48.6518 \\
& $\mathrm{H}^{*}, \mathrm{~kJ} / \mathrm{mol}$ & 116.689 \\
& $\mathrm{G}^{*}, \mathrm{~kJ} / \mathrm{mol}$ & 142.761 \\
Step 3 $\left(370-530{ }^{0} \mathrm{C}\right)$ & $\mathrm{Order}^{*}$ of decomposition & $3 / 2$ \\
& $\mathrm{E}^{*}, \mathrm{~kJ} / \mathrm{mol}$ & 142.557 \\
& $\mathrm{~A}, \mathrm{~S}^{-1}$ & $2.697 \mathrm{X} 10^{8}$ \\
& $\mathrm{~S}^{*}, \mathrm{~J} / \mathrm{K} / \mathrm{mol}$ & -33.669 \\
& $\mathrm{H}^{*}, \mathrm{~kJ} / \mathrm{mol}$ & 136.382 \\
& $\mathrm{G}^{*}, \mathrm{~kJ} / \mathrm{mol}$ & 161.387 \\
\hline
\end{tabular}

\section{Effect of initial pH on sorption process}

The $\mathrm{pH}$ of solution is an important parameter in the sorption process, as is evident from Figure 5(a) for $1 \mathrm{~h}$ sorption. The effect of $\mathrm{pH}$ on $\mathrm{Cu}$ sorption by WBAP was studied in the $\mathrm{pH}$ range 1.0 to 6.0 . The $\mathrm{pH}$ study was limited to value equal to 6.0 , because precipitation is observed after that. The $\mathrm{pH}$ values of metal solution were adjusted prior to the experiment with the $\mathrm{HNO}_{3}(2 \mathrm{~N})$ and $\mathrm{NaOH}(2 \mathrm{~N})$, and the $\mathrm{pH}$ value was not controlled during the experiment. The study was done with initial concentration of $210 \mathrm{mg} / \mathrm{L} \mathrm{Cu}$ and $20 \mathrm{~g} / \mathrm{L}$ WBAP dosage at $295 \mathrm{~K}$. It was evident from the plot that the uptake was almost constant at $\mathrm{pH} 3$ to 5 . The tremendous decrease in metal ion concentration in solution at $\mathrm{pH} 6.0$ may be due to the hydrolysis of $\mathrm{Cu}$, leading to precipitation. The $\mathrm{pH}$ of solution was measured before and after the sorption process, and an appreciable increase in $\mathrm{pH}$ of experimental solutions observed with initial $\mathrm{pH} 2.0$ and more. This may be attributed to the exchange of $\mathrm{Na}$ ions from the sorbent as is evident from Table 2, which summarizes $\mathrm{Cu}$ sorption by WBAP according to the initial $\mathrm{pH}$ of the solution. The variation in the removal of various metal ions can be explained by considering the surface charge of the WBAP. The composite ZPC of the sorbent is found to be 2.4. Thus below $\mathrm{pH}$ of 2.4 , the surface will have high positive charge density and under these conditions the uptake of $\mathrm{Cu}$ ions would be quite low due to electrostatic repulsion. With increasing $\mathrm{pH}$, i.e., beyond $\mathrm{ZPC}$ the negative charge on the surface of sorbent increases, thereby resulting in a sudden enhancement in metal sorption. As such copper gets sorbed at $\mathrm{pH}<2.0$. Thus, an improved sorption of copper ions on WBAP at low $\mathrm{pH}$ suggested that the process of metal ion uptake is sufficient energetic to 
overcome the net electrostatic repulsion. Since WBAP is efficient in removing $\mathrm{Cu}$ from aqueous solution with initial $\mathrm{pH}$ greater than 2 and the final $\mathrm{pH}$ reached to almost neutrality after sorption, it may be interesting choice for use in treatment of very acidic metal contaminated wastewater.

Table 2. $\mathrm{Cu}$ (II) removal from aqueous solution $\left(\mathrm{Cu}_{\mathrm{i}}=210 \mathrm{ppm}\right)$ adjusted at different $\mathrm{pH}$ after $24 \mathrm{~h}$ of sorption using $20 \mathrm{~g} / \mathrm{l} \mathrm{WBAP}$.

\begin{tabular}{llllll}
\hline $\mathrm{pH}_{\mathrm{i}}$ & $\mathrm{pH}_{\mathrm{f}}$ & $\mathrm{Cu}_{\mathrm{f}}, \mathrm{mg} / \mathrm{L}$ & $\%$ Removal & $\mathrm{x} / \mathrm{m}, \mathrm{mg} / \mathrm{g}$ & $\mathrm{Na}, \mathrm{mg} / \mathrm{L}$ \\
\hline 1.0 & $1.27 \pm 0.01$ & $175.3 \pm 0.12$ & 16.52 & 1.735 & $34 \pm 0.34$ \\
2.0 & $5.36 \pm 0.01$ & $54.64 \pm 0.04$ & 73.98 & 7.768 & $107 \pm 0.11$ \\
2.5 & $5.48 \pm 0.03$ & $24.44 \pm 0.17$ & 88.36 & 9.278 & $106 \pm 0.04$ \\
3.0 & $5.87 \pm 0.08$ & $14.17 \pm 0.09$ & 93.25 & 9.7915 & $113 \pm 0.02$ \\
4.0 & $5.93 \pm 0.28$ & $10.43 \pm 0.05$ & 95.03 & 9.9785 & $114 \pm 0.07$ \\
5.0 & $6.06 \pm 0.14$ & $7.40 \pm 0.07$ & 96.47 & 10.13 & $129 \pm 0.24$ \\
6.0 & $6.35 \pm 0.10$ & $4.90 \pm 0.05$ & 97.66 & 10.255 & $125 \pm 0.09$ \\
\hline
\end{tabular}

Effect of shaking time

The effect of shaking contact time was studied using an initial concentration of 200 $\mathrm{mg} / \mathrm{L}$ of $\mathrm{Cu}$ ion solution, $\mathrm{pH} 2.4$, stirring rate $100 \mathrm{rpm}$, and temperature $295 \mathrm{~K}$. The sorption of $\mathrm{Cu}$ has been investigated as a function of time in the range of 0 to 420 minutes. Figure 5(b) shows variation of percentage sorption and the metal uptake (mg $\mathrm{Cu}^{+2} / \mathrm{g}$ WBAP) with shaking time. The plot indicates that the remaining concentration of metal ion becomes asymptotic to time axis, such that there is no appreciable change in the metal ion concentration after 15 minutes of shaking time. The uptake of $\mathrm{Cu}$ ion by WBAP is very rapid; the metal uptake and percent sorption reach a maximum almost immediately after mixing of sorbent and sorbate. Sorption slowed down in later stages because initially a large number of vacant surface sites may be available for sorption and after some time, the remaining vacant surface sites may be difficult to occupy due to repulsive forces between solute molecules of solid (on the sorbent) and bulk phase.

\section{Effect of sorbent dosage}

The effect of various doses was studied at $295 \mathrm{~K}, \mathrm{pH} 2.0, \mathrm{Cu}^{+2}$ ion initial concentration 200 $\mathrm{mg} / \mathrm{L}$, and stirring rate $100 \mathrm{rpm}$. The sorption (percent removal of metal) increased with sorbent dose from 5 to $25 \mathrm{~g} / \mathrm{L}$ and then becomes almost constant, as is evident from Figure $5(\mathrm{c})$. The phenomenon of increase in percent $\mathrm{Cu}$ removal with increase in sorbent dose was due to the availability of more and more sorbent surfaces for solutes to be sorbed.

\section{Effect of initial metal ion concentration}

The equilibrium sorption isotherms are of fundamental importance in determining the sorption capacity and to diagnose the nature of sorption. The change in initial metal ion concentration of the feed affects the sorption. The effect of initial metal ion concentration on sorption was investigated over the concentration range $25-500 \mathrm{mg} / \mathrm{L}$ at fixed $\mathrm{pH}, 2.45$; temperature, $298 \mathrm{~K}$; contact time, 90 minute; and sorbent dose, $20 \mathrm{~g} / \mathrm{L}$. The results are shown in Figure 5(d). From the figure, it becomes clear that the sorption capacity increases as a function of concentration and becomes almost constant at $450 \mathrm{mg} / \mathrm{L}$ for $\mathrm{Cu}$ (II). 


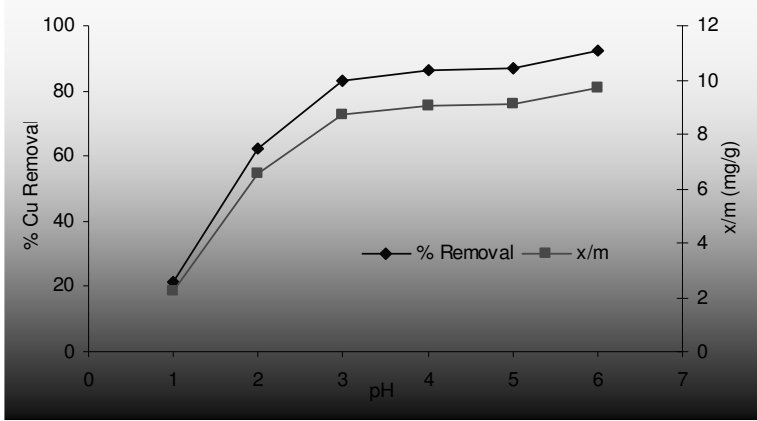

(a)

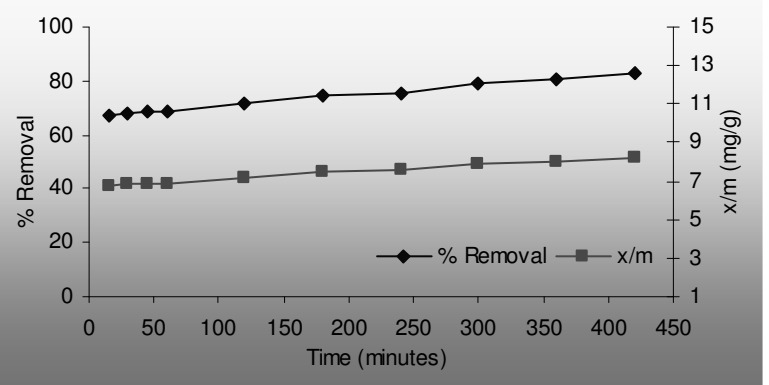

(b)

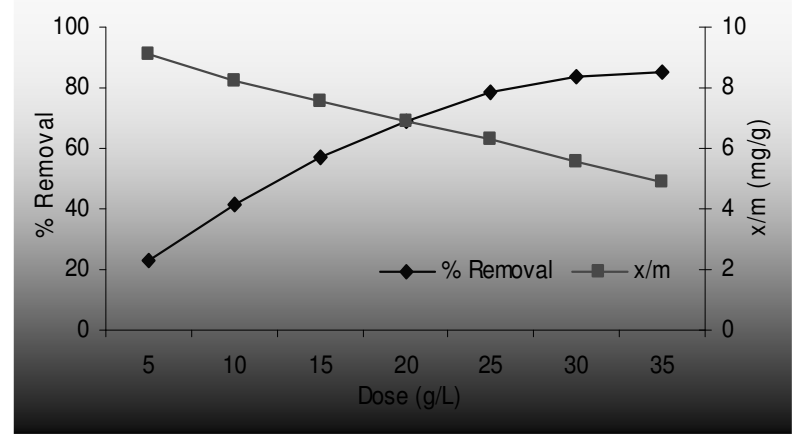

(c)

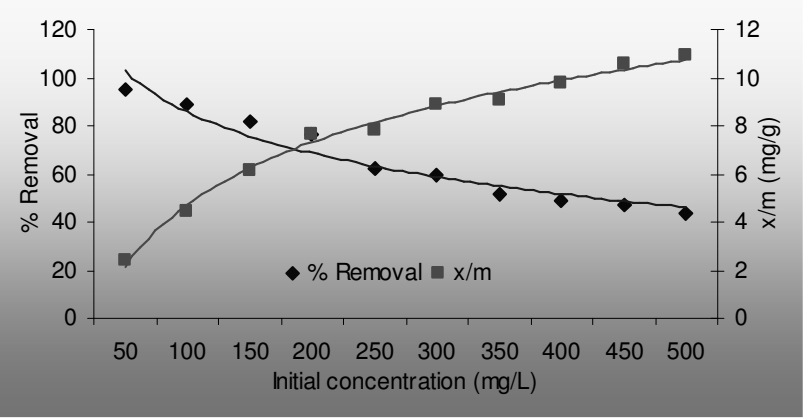

(d)

Figure 5. Effect of (a) pH, (b) shaking time, (c) sorbent dose, and (d) sorbate concentration on sorption of $\mathrm{Cu}^{+2}$ on WBAP. 


\section{Effect of temperature}

The influence of temperature was investigated at concentration of $1.588 \mathrm{mmol.dm}{ }^{-3}, 3.149$ mmol.dm ${ }^{-3}$, and 4.808 mmol.dm ${ }^{-3}$ at $\mathrm{T}=(276,295,313$, and 333) $\mathrm{K}, \mathrm{pH} \mathrm{2.45,} \mathrm{stirring} \mathrm{rate} 100$ $\mathrm{rpm}$, contact duration 90 minutes, and sorbent dosage $20 \mathrm{~g} / \mathrm{L}$. The sorption of $\mathrm{Cu}$ on WBAP increases with increase in temperature as shown in Figure. 6 indicates the process to be endothermic. This behavior may be attributed to a negative temperature coefficient of solubility of solutes. The increase in uptake of $\mathrm{Cu}^{+2}$ ions may be due to desolvation of sorbing species, change in the size of pores, and enhanced rate of intra particle diffusion of sorbate ${ }^{27}$.

The thermodynamic parameters were calculated from the slope and intercept of $\ln$ $\mathrm{K}_{\mathrm{d}}$ against $1 / \mathrm{T}$ (Figure 6 ) by using the equation

$$
\ln \mathrm{K}_{\mathrm{d}}=\left(\Delta \mathrm{S}^{0} / \mathrm{R}\right)-\left(\Delta \mathrm{H}^{0} / \mathrm{RT}\right)
$$

where $\mathrm{K}_{\mathrm{d}}$ is distribution coefficient, $\Delta \mathrm{H}^{0}, \Delta \mathrm{S}^{0}$, R, and T are the enthalpy, entropy, gas constant, and temperature in Kelvin, respectively. Gibbs free energy $\left(\Delta G^{0}\right)$ of specific sorption was calculated from the well known equation

$$
\Delta \mathrm{G}^{0}=\Delta \mathrm{H}^{0}-\mathrm{T} . \Delta \mathrm{S}^{0}
$$

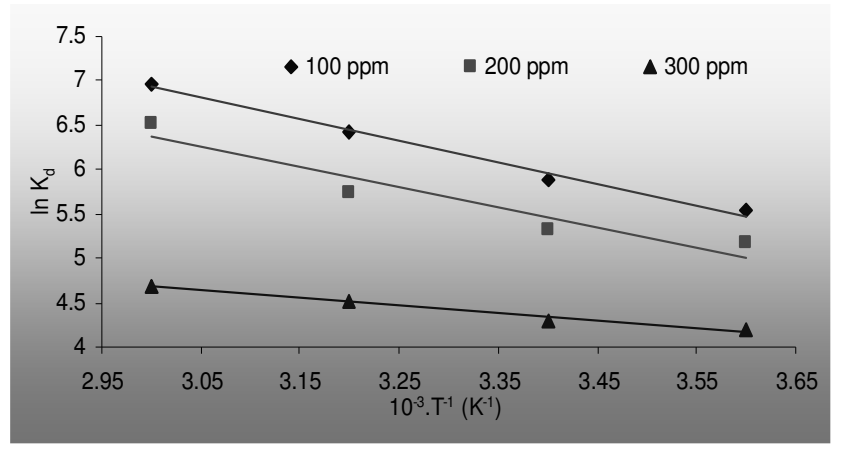

Figure 6. Effect of temperature on thermodynamic behavior of sorption of $\mathrm{Cu}^{+2}$

The values of thermodynamic parameters for the sorption of $\mathrm{Cu}$ ions on WBAP are given in Table 3. The positive value of $\Delta \mathrm{H}^{0}$, shows the sorption process to be endothermic. The Gibbs free energy is negative and increases towards negative side with rise in temperature, indicating the sorption process to be spontaneous in nature without any induction period and more favorable at higher temperature. The endothermicity of the heat of sorption may be due to the removal of water molecules from the solid/solution interface and from the sorbing cations. The $\Delta \mathrm{G}^{0}$ value increases towards positive side with rise in $\mathrm{Cu}^{+2}$ ion concentration, indicating reduction in spontaneity with increase in the ions to be sorbed. Also the positive value of $\Delta \mathrm{S}^{0}$ favors the complexation and is an indication for stability of sorption.

Table 3. Thermodynamic parameters for the sorption of $\mathrm{Cu}^{+2}$ on WBAP.

\begin{tabular}{ccccccc}
\hline $\begin{array}{c}\text { Concentration } \\
\text { of } \mathrm{Cu}^{+2}\end{array}$ & $\begin{array}{c}\Delta \mathrm{H}^{0} \\
\mathrm{~kJ} / \mathrm{mol}\end{array}$ & $\begin{array}{c}\Delta / \mathrm{S} / \mathrm{K} / \mathrm{mol} \\
\mathrm{J}\end{array}$ & $276 \mathrm{~K}$ & $295 \mathrm{~K}$ & $313 \mathrm{~K}$ & $333 \mathrm{~K}$ \\
\hline $100 \mathrm{mg} / \mathrm{L}$ & 4.0406 & 61.69 & 12.985 & 14.158 & 15.268 & 16.502 \\
$200 \mathrm{mg} / \mathrm{L}$ & 3.8160 & 56.6599 & 11.822 & 12.898 & 13.918 & 15.052 \\
$300 \mathrm{mg} / \mathrm{L}$ & 1.4050 & 37.2882 & 8.8860 & 9.595 & 10.266 & 11.011 \\
\hline
\end{tabular}


Competitive sorption of $\mathrm{Cu}^{+2}$ ions from binary, ternary, and multi elemental true sample

The effect of the presence of $\mathrm{Ni}^{+2}$ and $\mathrm{Cr}^{+3}$ ions on the sorption of $\mathrm{Cu}^{+2}$ ions was investigated in the binary and ternary mixture. These ions were selected as they were the constituent of electroplating industry wastewater under study. The initial concentration of these ions was $200 \mathrm{mg} / \mathrm{L}$. The $\mathrm{pH}$ was adjusted to 2.55 , stirring rate $100 \mathrm{rpm}$, and sorbent dosage $20 \mathrm{~g} / \mathrm{L}$. The temperature of the system maintained at $292 \mathrm{~K}$. The amount of metal ion sorbed per gram of WBAP was found to be reduced in the presence of other metal ions.

It was observed that the amount of $\mathrm{Cu}^{+2}$ ions sorbed per gram of sorbent was reduced to $6.485 \mathrm{mg} / \mathrm{g}(64.85 \%)$ in presence of $\mathrm{Ni}, 6.211 \mathrm{mg} / \mathrm{g}(62.11 \%)$ in presence of $\mathrm{Cr}$, and $5.978 \mathrm{mg} / \mathrm{g}(59.78 \%)$ in presence of $(\mathrm{Ni}+\mathrm{Cr})$ ions as compared to $7.678 \mathrm{mg} / \mathrm{g}(76.78 \%)$ for single element study.

Comparing a true sample taken from an electroplating industry and laboratory single element sample showed that uptake of metal reduced to $5.752 \mathrm{mg} / \mathrm{g}(57.52 \%)$. The decrease in uptake may be attributed to the presence of other ions and impurities in the effluent samples. It is clear from the results of laboratory simulated ternary sample and true effluent sample that the decrease is very small in presence of interfering ions like sodium, potassium, calcium, magnesium, chlorides, sulfate, etc. which are present in the effluent water, so the sorbent can be used for the removal of $\mathrm{Cu}^{+2}$ in presence of interfering ions.

\section{Sorption Kinetics}

The sorbent phase concentration of the $\mathrm{Cu}(\mathrm{q}) v s$. time $(\mathrm{t})$ data were further processed for deriving the rate constant $\left(\mathrm{K}_{\mathrm{ads}}\right)$ of sorption and for testing the role of diffusion on the sorption process.

\section{Pseudo first order model}

Dynamic modeling of $\mathrm{Cu}$ uptake on WBAP showed that Lagergren's first order rate equation $^{28,29}$.

$$
\log \left(\mathrm{q}_{\mathrm{e}}-\mathrm{q}\right)=\log \mathrm{q}_{\mathrm{e}}-\mathrm{K}_{\mathrm{f}} \mathrm{t} / 2.303
$$

(where, $\mathrm{q}_{\mathrm{e}}$ and $\mathrm{q}$ are equilibrium and instantaneous sorbate concentrations in the sorbent $(\mathrm{mg} / \mathrm{g})$, respectively, $\mathrm{t}$ is time $(\mathrm{min})$, and $\mathrm{K}_{\mathrm{f}}$ is the $1^{\text {st }}$ order rate constant $\left(\min ^{-1}\right)$ ) was applicable yielding an almost constant slope and good correlation coefficients (0.9925-0.9984) for semi logarithmic linear curve (Figure 7(a)). The calculated rate constants were slightly dependent on the initial solution concentration. The linear plots did not pass through the origin possibly because the $\mathrm{q}_{\mathrm{e}}$ values (0.6593, 1.3471, and $2.667 \mathrm{mg} / \mathrm{g}$ for $100 \mathrm{mg} / \mathrm{L}, 200 \mathrm{mg} / \mathrm{L}$, and $300 \mathrm{mg} / \mathrm{L}$ respectively) dependent on the initial concentration of the sorbate were well below the monolayer capacities founded by equilibrium modeling and the slight dependence of $K_{f}$ on $C_{o}$ (Table 4) may be indicative of a more complex reaction which may be approximated by a pseudo-first order rate expression. 


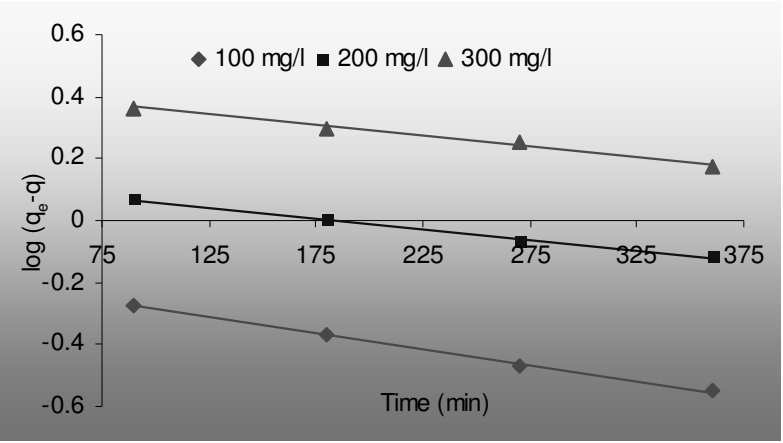

(a)

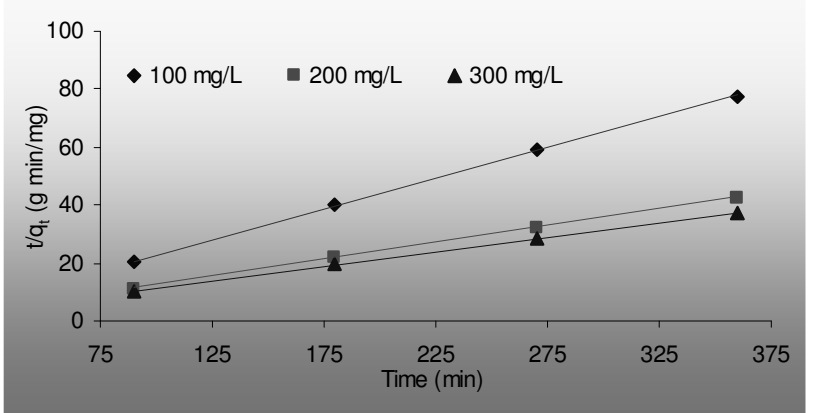

(b)

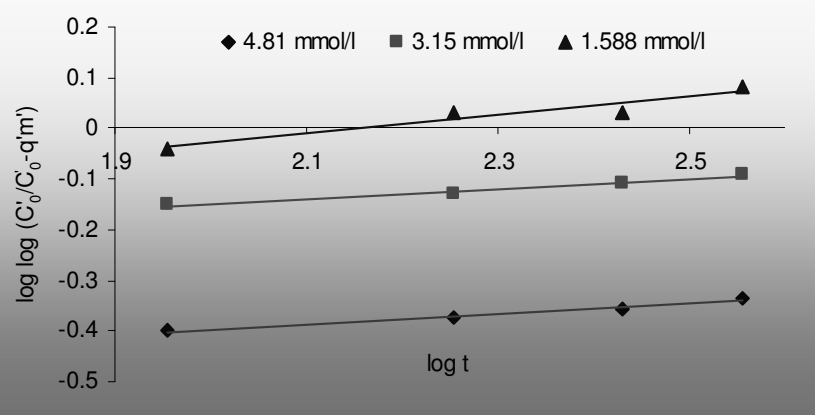

(c)

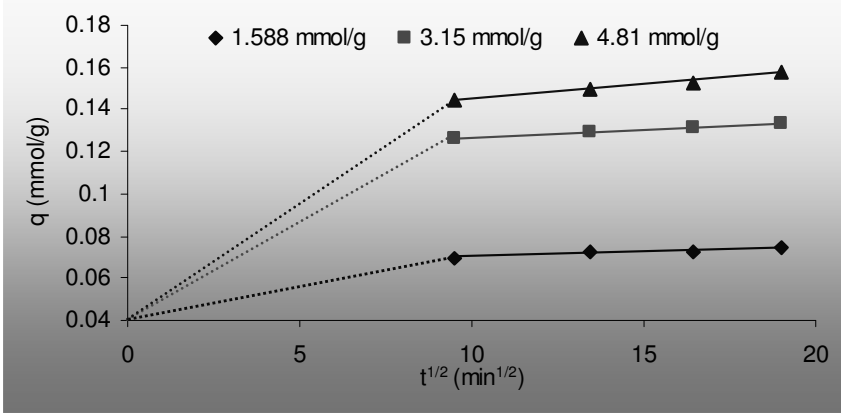

(d)

Figure 7. (a) Lagergren's plot, (b) Pseudo second order plot, (c) Bangham's plot, and (d) Weber and Morris plot for dynamic study of $\mathrm{Cu}^{+2}$ sorption on WBAP. 
Table 4. Kinetic parameters of removal of $\mathrm{Cu}$ (II) by WBAP $(\mathrm{T}=295 \mathrm{~K}, \mathrm{~m}=20 \mathrm{~g} / \mathrm{L}, \mathrm{pH}=2.46$, Stirring rate $=100 \mathrm{rpm})$.

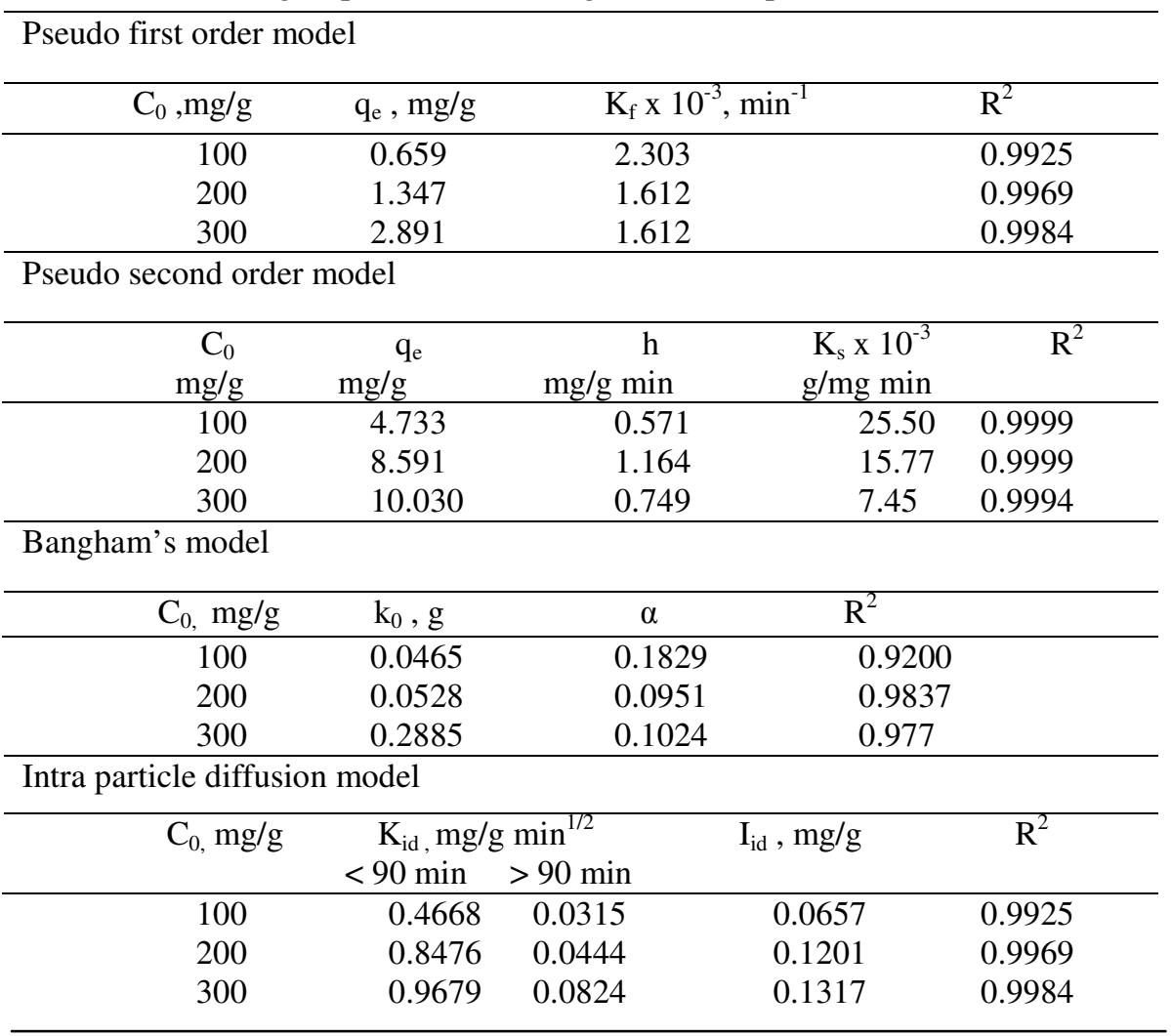

\section{Pseudo second order}

The pseudo-second-order model can be represented in the following form ${ }^{30}$ :

$$
\mathrm{dq} / \mathrm{d}_{\mathrm{t}}=\mathrm{K}_{\mathrm{s}}\left(\mathrm{q}_{\mathrm{e}}-\mathrm{q}\right)^{2}
$$

where $\mathrm{K}_{\mathrm{s}}$ is the pseudo-second-order rate constant $(\mathrm{g} / \mathrm{mg} / \mathrm{min})$. After integrating the equation for boundary conditions $\mathrm{q}_{\mathrm{t}}=0$ at $\mathrm{t}=0$ and $\mathrm{q}_{\mathrm{t}}=\mathrm{q}_{\mathrm{t}}$, at $\mathrm{t}=\mathrm{t}$ the following equation is obtained:

$$
\mathrm{t} / \mathrm{q}_{\mathrm{t}}=1 /\left(\mathrm{K}_{\mathrm{s}} \cdot \mathrm{q}_{\mathrm{e}}^{2}\right)+\mathrm{t} / \mathrm{q}_{\mathrm{e}}
$$

The initial sorption rate, $\mathrm{h}(\mathrm{mg} / \mathrm{g} / \mathrm{min})$, at $t \rightarrow 0$ is defined as:

$$
\mathrm{h}=\mathrm{K}_{\mathrm{s}} \cdot \mathrm{q}_{\mathrm{e}}^{2}
$$

The equilibrium sorption capacity, $\mathrm{q}_{\mathrm{e}}$ is obtained from the slope of the plot $\mathrm{t} / \mathrm{q}_{\mathrm{t}}$ versus $\mathrm{t}$, and the initial sorption rate $\mathrm{h}$ is obtained from the intercept. Since $\mathrm{q}_{\mathrm{e}}$ is known from the slope, the pseudo second order constant $\mathrm{K}_{\mathrm{s}}$ can be determined from the value of the initial sorption rate. The best fit values of $\mathrm{h}, \mathrm{q}_{\mathrm{e}}$, and $\mathrm{K}_{\mathrm{s}}$ along with correlation coefficients for the pseudo first order and pseudo second order models are shown in Table 4. The calculated correlation coefficients are more closer to unity for pseudo second order kinetics than that for the pseudo first order kinetic model. Therefore, the sorption can be approximated more appropriately by the pseudo second order kinetic model for the sorption of $\mathrm{Cu}$ by WBAP. 
Table 5. Langmuir, Freundlich, DKR, and Temkin parameters of sorption isotherm for $\mathrm{Cu}$ (II) on WBAP.

\begin{tabular}{ll}
\hline Parameters & Value \\
\hline Langmuir isotherm & \\
$\mathrm{Q}_{0}, \mathrm{mg} / \mathrm{g}$ & 9.45 \\
$\mathrm{~b}, \mathrm{~L} / \mathrm{mg}$ & 0.05219 \\
$\mathrm{R}^{2}$ & 0.9145 \\
$\mathrm{R}_{\mathrm{L}}$ & 0.0872 \\
Freundlich isotherm & \\
$1 / \mathrm{n}$ & 0.2645 \\
$\mathrm{~K}$ & 2.3480 \\
$\mathrm{R}^{2}$ & 0.9868 \\
$\mathrm{DKR}$ isotherm & \\
$\mathrm{Xm}, \mathrm{mmol} / \mathrm{g}$ & 6.498 \\
$\mathrm{~B}, \mathrm{~mol}{ }^{2} / \mathrm{J}^{2}$ & $-0.2 \times 10^{-8}$ \\
$\mathrm{E}, \mathrm{kJ} / \mathrm{mol}$ & 15.811 \\
$\mathrm{R}^{2}$ & 0.9886 \\
$\mathrm{Temkin}$ isotherm & \\
$\mathrm{K}_{\mathrm{t}}, \mathrm{L} / \mathrm{mg}$ & 0.6504 \\
$\mathrm{~B}_{1}$ & 4.4097 \\
$\mathrm{R}^{2}$ & 0.9681 \\
\hline
\end{tabular}

\section{Bangham's equation}

Bangham's equation ${ }^{31}$ was employed for its applicability to $\mathrm{Cu}^{+2}$ sorption, whether the sorption process is diffusion controlled.

$\log \log \left(\mathrm{C}_{0}^{\prime} / \mathrm{C}_{0}{ }^{\prime}-\mathrm{q}^{\prime} \mathrm{m}^{\prime}\right)=\log \left(\mathrm{K}_{0} \mathrm{~m}^{\prime} / 2.303 \mathrm{~V}\right)+\alpha \log \mathrm{t}$

where $\mathrm{C}_{0}$ is initial concentration of sorbate in solution $(\mathrm{mmol} / \mathrm{L}), \mathrm{V}$ is volume of solution $(\mathrm{mL}), \mathrm{m}^{\prime}$ is weight of sorbent used per liter of solution $(\mathrm{g} / \mathrm{L}), \mathrm{q}$ ' is the amount of sorbate retained at time $\mathrm{t}(\mathrm{mmol} / \mathrm{g}), \alpha$ and $\mathrm{k}_{0}$ are constants. The double logarithmic plot according to equation (11) yielded perfectly linear curves (Figure 7(c)) showing that the diffusion of the sorbate into the pores of the sorbent basically controls the sorption process.

\section{Intra particle diffusion study}

The possibility of intra particle diffusion resistance affecting sorption was tested by the aid of 'Weber and Morris' method ${ }^{32}$ :

$$
\mathrm{q}_{\mathrm{t}}=\mathrm{k}_{\mathrm{id} .} \mathrm{t}^{1 / 2}+\mathrm{I}
$$

where $\mathrm{q}_{\mathrm{t}}$ is the amount of sorbate retained at time $\mathrm{t}(\mathrm{mmol} / \mathrm{g})$ and $\mathrm{k}_{\mathrm{id}}$ is a constant. The plot of $\mathrm{q}_{\mathrm{t}}$ versus $\mathrm{t}^{1 / 2}$ is presented in Figure. 7(d). The value of I (Table 4) gives an idea about the thickness of the boundary layer, i.e. the larger the intercept the greater the boundary layer effect. Furthermore, such deviation of straight line from the origin indicates that pore diffusion may not be the only rate controlling step in the removal of sorbate.

\section{Sorption isotherms}

Sorption isotherms of WBAP for $\mathrm{Cu}$ ions were expressed mathematically in terms of the Langmuir ${ }^{33}$, Freundlich ${ }^{34}$, Dubinin-Kaganer-Radushkevick (DKR) ${ }^{35,36}$, and Temkin ${ }^{37}$ 
models. The obtained experimental data are commonly well fitted with the Langmuir (Eq. 13), Freundlich (Eq. 14), DKR (Eq.15) and Temkin model (Eq. 18) models.

$$
1 / q_{\mathrm{e}}=1 / \mathrm{Q}_{0}+1 / \mathrm{Q}_{0} \cdot \mathrm{b} \cdot \mathrm{C}_{\mathrm{e}}
$$

where $\mathrm{q}_{\mathrm{e}}$ is the amount sorbed $(\mathrm{mg} / \mathrm{g}), \mathrm{C}_{\mathrm{e}}$ is the equilibrium concentration of the sorbate (mg/L), and $\mathrm{Q}_{0}$ and $\mathrm{b}$ are the Langmuir constants related to maximum sorption capacity and energy of sorption, respectively.

$$
\log \mathrm{q}_{\mathrm{e}}=\log \mathrm{K}+1 / \mathrm{n} \log \mathrm{C}_{\mathrm{e}}
$$

where $\mathrm{q}_{\mathrm{e}}$ is the amount sorbed $(\mathrm{mg} / \mathrm{g}), \mathrm{C}_{\mathrm{e}}$ is the equilibrium concentration of the sorbate $(\mathrm{mg} / \mathrm{L})$, and $\mathrm{K}$ and $\mathrm{n}$ are Freundlich constants related to sorption capacity and sorption intensity, respectively.

$$
\ln \mathrm{q}_{\mathrm{e}}=\ln \mathrm{X}_{\mathrm{m}}-\beta \varepsilon^{2}
$$

where $\mathrm{q}_{\mathrm{e}}$ is the amount sorbed (mg/g), $\mathrm{X}_{\mathrm{m}}$ is DKR monolayer capacity, $\beta$ is the activity coefficient related to mean sorption energy, and $\varepsilon$ is Polanyi potential, which is equal to

$$
\varepsilon=\mathrm{RT} \ln \left(1 / \mathrm{C}_{\mathrm{e}}\right)
$$

where $R$ is gas constant $(\mathrm{J} / \mathrm{K} / \mathrm{mol}), T$ is temperature (Kelvin), and $\mathrm{C}_{\mathrm{e}}$ is the equilibrium concentration of the sorbate $(\mathrm{mg} / \mathrm{L})$. When $\ln \mathrm{q}_{\mathrm{e}}$ is plotted against $\varepsilon^{2}$, a straight line is obtained. The slope of the plot gives the value of $\beta$ and the intercept yields the value of sorption capacity, $X_{m}$. The value of $\beta$ is related to sorption energy, E, via following relationship:

$$
\mathrm{E}=-1 /(-2 \beta)^{1 / 2}
$$

Temkin isotherm contains a factor that explicitly takes into account sorbate species -sorbent interactions. This isotherm assumes that: (i) the heat of adsorption of all the molecules in the layer decreases linearly with coverage due to sorbate species-sorbent interactions, and (ii) adsorption is characterized by a uniform distribution of binding energies, up to some maximum binding energy.

$$
\mathrm{q}_{\mathrm{e}}=\mathrm{B}_{1} \ln \mathrm{K}_{\mathrm{t}}+\mathrm{B}_{1} \ln \mathrm{C}_{\mathrm{e}}
$$

where $\mathrm{B}_{1}=\mathrm{RT} / \mathrm{b}$ and $\mathrm{K}_{\mathrm{t}}$ are the constants. $\mathrm{K}_{\mathrm{t}}$ is the equilibrium binding constant $(\mathrm{l} / \mathrm{mol})$ corresponding to maximum binding energy and constant $\mathrm{B}_{1}$ is related to the heat of sorption. $\mathrm{A}$ plot of qe versus $\ln \mathrm{C}_{\mathrm{e}}$ enables the determination of the isotherm constants $\mathrm{K}_{t}$ and $\mathrm{B}_{1}$.

The linearized form of isotherm models using equations (13), (14), (15) and (18) for $\mathrm{Cu}$ removal by WBAP can be seen in Figure 8 . The correlation factors and other parameters for Freundlich, Langmuir, DKR, and Temkin isotherm are presented in Table 5. The correlation factors (0.9145 - 0.989) confirms good agreement between theoretical models and our experimental results. The correlation coefficients for Freundlich isotherm are highest in comparison to the values obtained for the Langmuir, DKR, and Temkin isotherms. Therefore, Freundlich equation is found to best fit the equilibrium data for sorption of $\mathrm{Cu}$ ions on WBAP. The $1 / \mathrm{n}<<1$ indicates that sorption capacity is slightly suppressed at lower equilibrium concentration. This isotherm does not predict any saturation of the sorbent by the sorbate; thus infinite surface coverage is predicted mathematically, indicating multilayer sorption on the surface. The sorption capacity of WBAP for $\mathrm{Cu}$ at pH 2.4 and $295 \mathrm{~K}$ was found to be $9.45 \mathrm{mg} / \mathrm{g}$. The sorption capacity obtained for WBAP is found to be comparable to and in some cases better than, the other sorbents and activated carbons as reported for coal fly $\operatorname{ash}^{38}(1.257 \mathrm{mg} / \mathrm{g})$, sphagnum peat moss ${ }^{39}(16.1 \mathrm{mg} / \mathrm{gm})$, bagasse fly ash ${ }^{40}$ $(2.26 \mathrm{mg} / \mathrm{g})$, goethite ${ }^{41}(6.685 \mathrm{mg} / \mathrm{g})$, raw chitosan powder ${ }^{42}(24.13 \mathrm{mg} / \mathrm{g})$, and $\mathrm{Fe}_{3} \mathrm{O}_{4}$-chitosan nano particles $^{43}(6.35 \mathrm{mg} / \mathrm{g})$.

The influence of sorption isotherm shape to know whether the sorption is favorable or not, has been discussed in terms of a dimensionless constant $\mathrm{R}_{\mathrm{L}}$; referred to as separation factor $^{44,45}$, defined as follows: 


$$
\mathrm{R}_{\mathrm{L}}=1 /\left(1+\mathrm{b} . \mathrm{C}_{0}\right)
$$

Where $b$ is Langmuir constant $(1 / \mathrm{mg})$ and $\mathrm{C}_{0}$ the initial concentration $(\mathrm{mg} / \mathrm{L})$. The value of $R_{L}$ was found to be 0.08742 . This indicates a highly favorable sorption.

The numerical value of mean sorption energy $\mathrm{E}$ from DKR isotherm is useful in estimating the type of sorption, i.e. an energy range from 1.00 to 8.00 and $8.00-16.00 \mathrm{~kJ} / \mathrm{mol}$ is for physical and chemical sorption, respectively. The E values found for this study are of the order expected of an ion exchange mechanism. The sorption capacity $\mathrm{X}_{\mathrm{m}}$ was found to be $0.1243 \mathrm{mmol} / \mathrm{g}$ for $\mathrm{Cu}^{+2}$.

It may be conclude from the correlation value that the Langmuir sorption isotherm does not represent the equilibrium data satisfactorily.

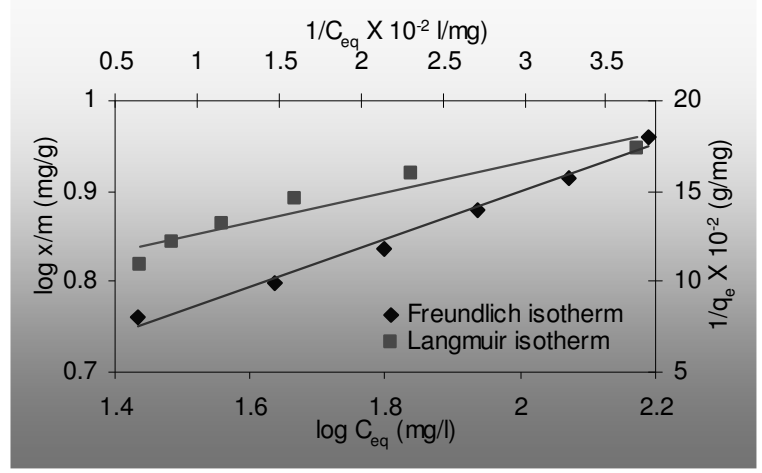

(a)

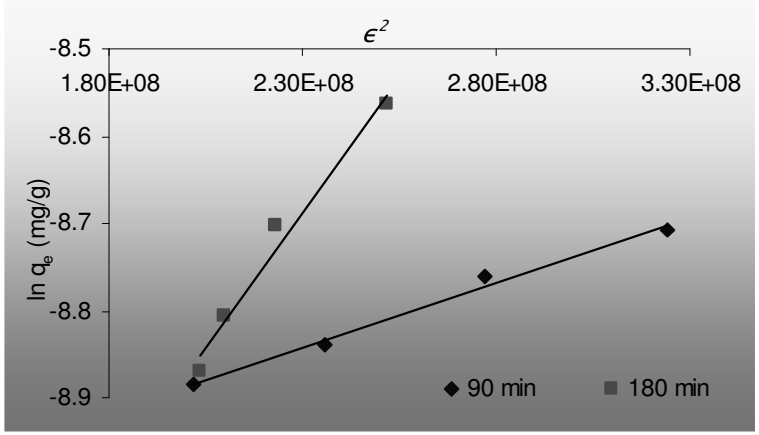

(b)

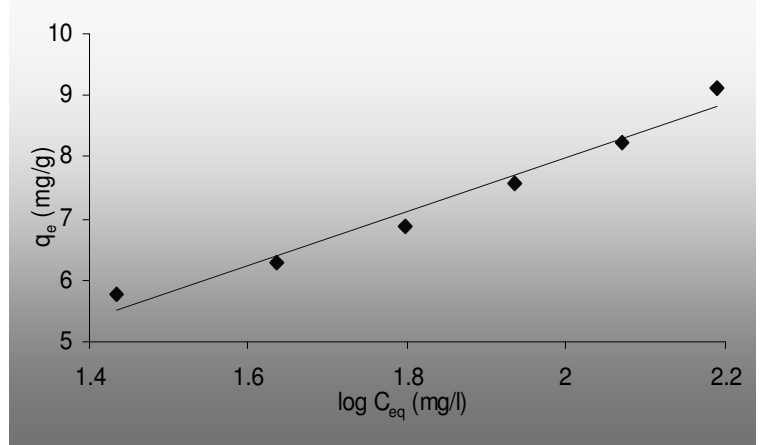

(c)

Figure 8. (a) Freundlich and Langmuir, (b) DKR, and (c) Temkin isotherm for sorption of $\mathrm{Cu}^{+2}$ on WBAP. 


\section{Conclusions}

The results of this study indicate that the WBAP procured from Kutch region of Gujarat (India), has the ability to remove considerable quantities of $\mathrm{Cu}^{+2}$ ions from acidic solution/wastewater. The major advantage is the low cost recovery process that makes it suitable in water purification. Also, $\mathrm{pH}$ of the treated wastewater reached to almost neutrality, thereby saving the cost for neutralizing chemicals.

On the basis of good sorption ability shown by WBAP for $\mathrm{Cu}^{+2}$ in presence of other metal ions and their removal in binary, ternary, and multi elemental systems by batch experiment suggests that this sorbent has the potential of application for the removal of several heavy metals contained in wastewater.

The sorption process is pseudo second order with pore diffusion being the essential rate controlling step. The uptake of $\mathrm{Cu}^{+2}$ ions by WBAP is endothermic in nature, as $\Delta \mathrm{H}^{0}$ values are positive. Since $\Delta \mathrm{H}^{0}$ is relatively of small magnitude, the forces of positive uptake are weak. The negative value $\Delta G^{0}$ indicates a spontaneous sorption process. The positive value of $\Delta S^{0}$ shows some structural change at the solid liquid interface.

Sorption of copper ions on WBAP followed Freundlich model. The value of ' $n$ ' is 3.781 , indicates a favorable sorption process. The value of mean sorption energy indicates the sorption process following ion exchange mechanism.

\section{References}

1. Zuane J D, Handbook of Drinking Water Quality: Standards and Control, Van Nostrand Reinhold, New York, 1990.

2. Stumm W, Morgan J J, The Solid - Solution Interface, Aquatic Chemistry, Chemical Equilibria and Rates in Natural Waters, Wiley interscience, USA, 1996.

3. $\quad$ Brower J B, Ryan R L, Pazirandeh M, Environ. Sci. Technol., 1997, 31, 2910.

4. $\quad$ Namasivayam C, Ranganathan K, Water Res., 1995, 29, 1737.

5. $\quad$ Ricou P H, Lecuyer I, Le Cloirec P, Water Res., 2001, 35, 965.

6. $\quad$ Camp R T,. Water and Its Impurities, $2^{\text {nd }}$ Ed., Reinhold, New York, 1964.

7. Dean J C, Bosqui F L, Lanovette K H, Envir. Sci. Technol. 1972, 6, 518.

8. Mcculloch J K, Perera J M, Kelly E D, White L R, Stevens G W, Grieser F A, J. Colloid Interface Sci. 1996, 184, 406.

9. Rengaraj S, Kim Y, Joo C K, Choi K, Yi J, Korean J. Chem. Eng. 2004, 21, 187.

10. Pollard S J T, Fowler G F, Sollars C J, Perry R, Sci. Total Environ. 1992, 116, 31.

11. Gupta V K, Sharma S, Ind. Eng. Chem. Res. 2003, 42, 6619.

12. Manju G N, Raji C, Anirudhan T S, Water Res. 1998, 32, 3062.

13. Bailey S E, Trudy J O, Bricka R M, Adrian D D, Water Res. 1999, 33, 2469.

14. Blais J F, Meunier N, Laroulandie J, Tyagi R D, Bioresour. Technol. 2003, 90, 255.

15. Kumar A, Rao N N, Kaul S N, Bioresour. Technol. 2000, 71, 133.

16. Comons R N J, Water Res. 1987, 21, 1573.

17. Srivastava S K, Tyagi R, Pant N, Pal N, Environ. Technol. Lett. 1989, 10, 275.

18. Kara M, Yuzer H, Sabah E, Celik M S, Water Res. 2003, 37, 224.

19. Rauf N, Tahir S S, J. of Environmental Management. 2004, 73, 285.

20. Tsai, W T, Lai C W, Su T Y, J. Hazard. Mater. 2006, 134, 169.

21. You C F, Lee T, Li Y H, Chem Geol. 1989, 77, 105.

22. Corbin D R, Burgess B F, Vega A J, Faelee R D, Anal. Chem. 1987, 59, 2722. 
23. Vogel A I, A Textbook of Quantitative Chemical Analysis, 5 ${ }^{\text {th }}$ Ed., ELBS publication, London, 1989.

24. APHA. Standard Methods for the Examination of Water and Wastewater, $18^{\text {th }}$ Ed., APHA, Washington, DC, 1992.

25. Coats A W, Redfern J P, Nature. 1964, 201, 68.

26. Schwarz J A, Driscoll C T, Bhanot A K, J. Colloid Interf Sci. 1984, 97, 55.

27. Knocke W R, Hemphill L H, Water Res. 1981, 15, 275.

28. Ho Y S, McKay G, Water Res. 1999, 33, 578.

29. Haribabu E, Upadhya Y D, Upadhyaya S N, Int. J. Environ. Studies. 1993, 43, 169.

30. Ho Y S, McKay G, Water Res. 1999, 33, 735.

31. Tutem E, Apak R, Unal C F, Water Res. 1998, 32, 2315.

32. Weber W J, Morris J C, J. San. Eng. Div. ASCE. 1963, 89(SA2), 31.

33. Langmuir I, J. Am. Chem. Soc. 1918, 40, 1361.

34. Freundlich H, Hatfield H, Colloid and Capillary Chemistry, Methuen \& Co. Ltd., London, 1926.

35. Hutson N D, Yang R T, Adsorption. 1997, 3, 189.

36. Krishna B S, Murty D S R, Jai Prakash B S, J. Colloid Interf Sci. 2000, 229, 230.

37. Mall I D, Srivastava V C, Agarwal N K, Dyes and Pigments. 2006, 69, 210.

38. Pandey K K, Prasad G, Singh V N, Water Res. 1985, 19, 869.

39. Gardea-Torresdey J L, Tang L, Salvador J M, J J. Hazard. Mater. 1996, 48, 191.

40. Gupta V K, Ali I, Separation and Purification Technology. 2000, 18, 131.

41. Acemioglu B, Alma M H, J. Colloid Interf Sci. 2001, 243, 81.

42. Lima I S, Airoldi C, Thermochim. Acta. 2004, 421, 133.

43. Chang Y C, Chen D H, J. Colloid Interf Sci. 2005, 283, 446.

44. Weber T W, Chakravorti R K, J Am. Inst. Chem. Eng. 1974, 20, 228.

45. McKay G, Otterburn M S, Sweeney A G, Water Res. 1980, 14, 21. 


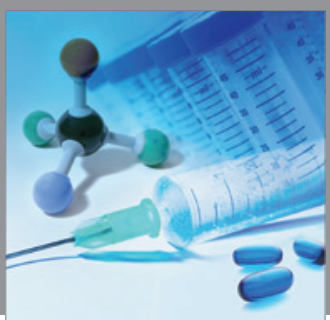

International Journal of

Medicinal Chemistry

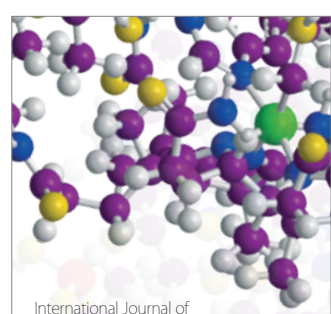

Carbohydrate Chemistry

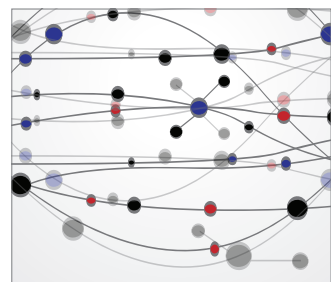

The Scientific World Journal
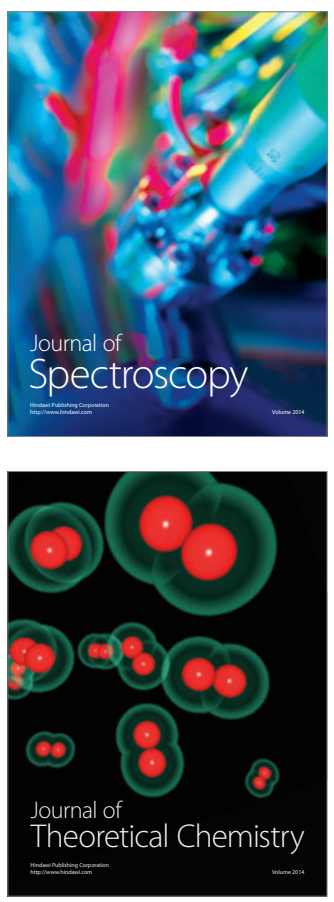
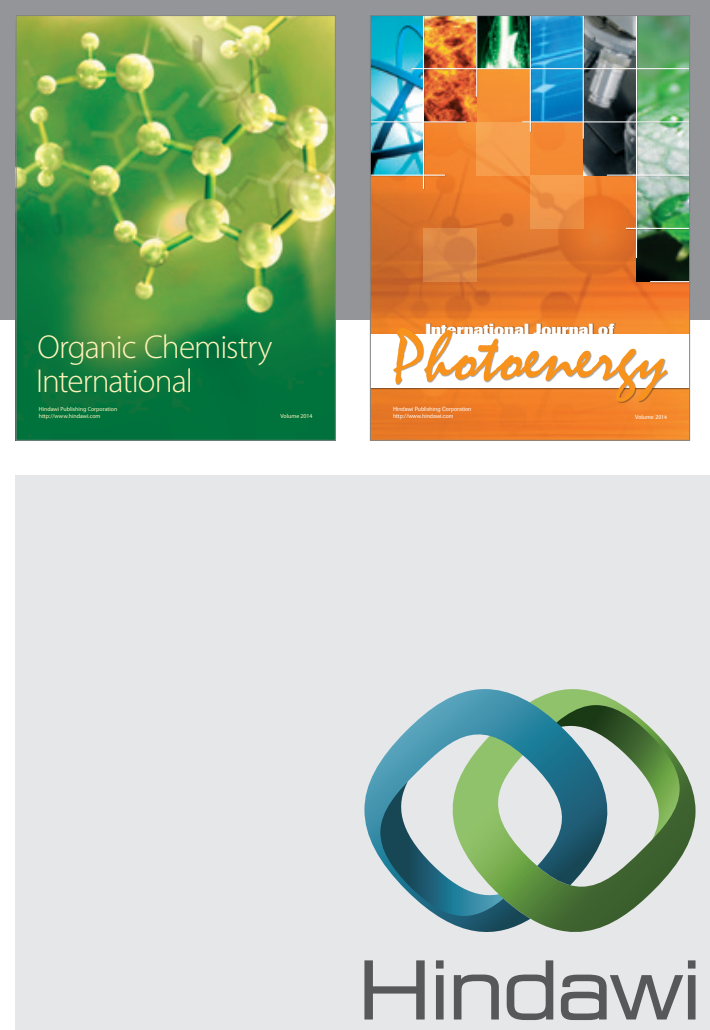

Submit your manuscripts at

http://www.hindawi.com
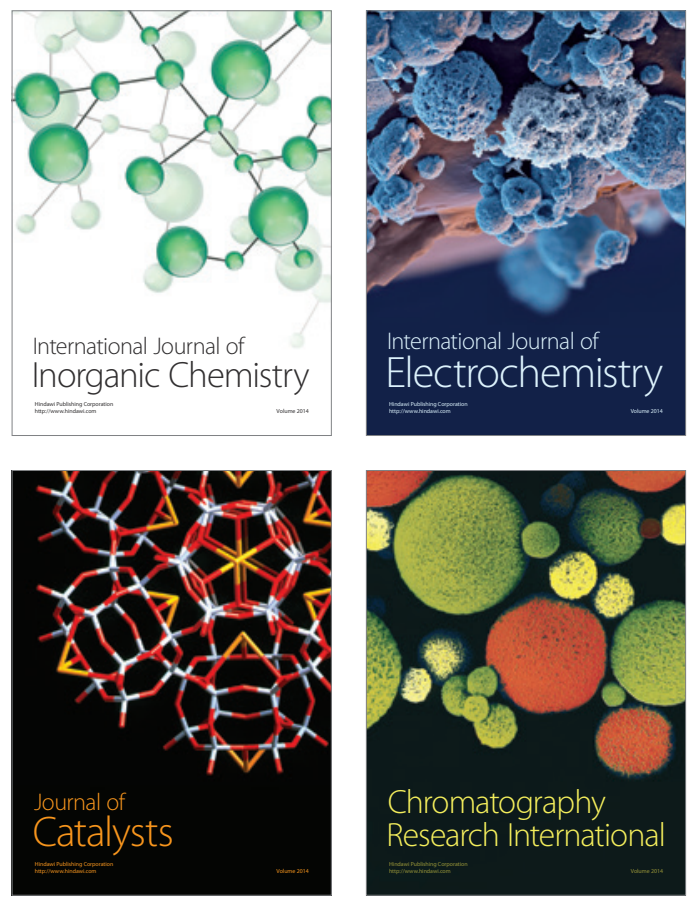
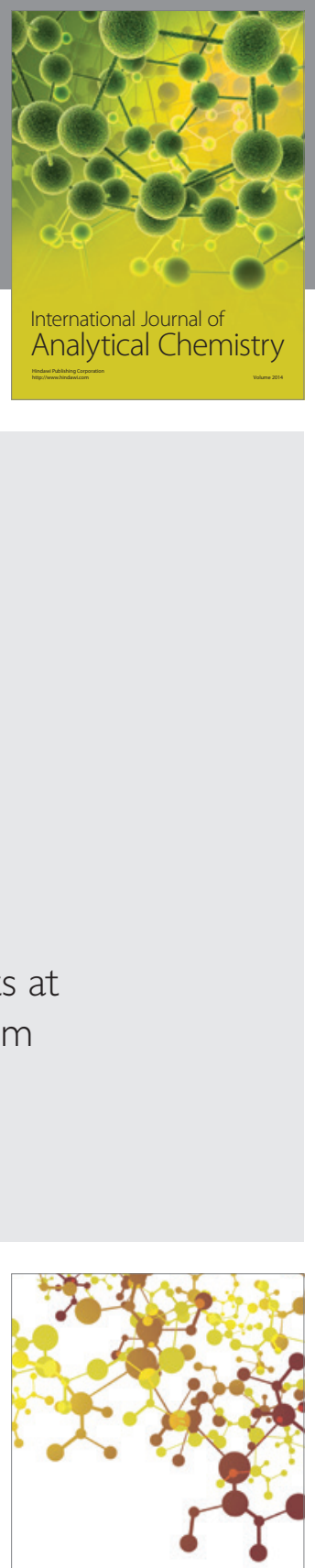

Journal of

Applied Chemistry
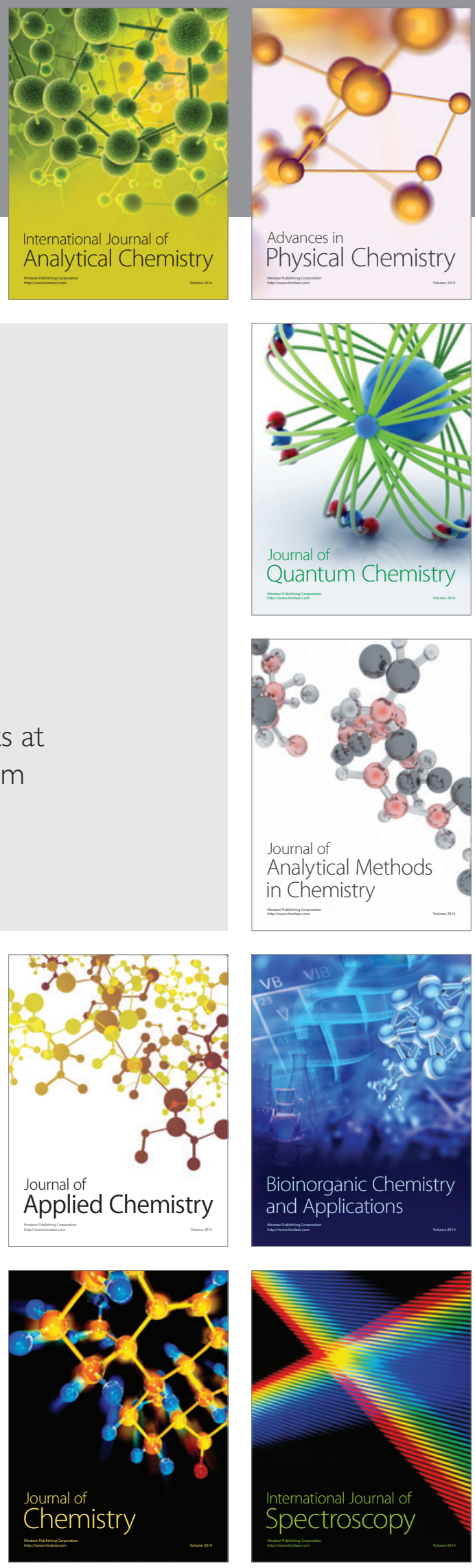